\title{
Correction: the ER stress inducer DMC enhances TRAIL-induced apoptosis in glioblastoma
}

\author{
Ingrid AM van Roosmalen ${ }^{1,2}$, Carlos R Reis ${ }^{1,3+}{ }^{+}$, Rita Setroikromo ${ }^{1}$, Saravanan Yuvaraj ${ }^{2,4}$, Justin V Joseph ${ }^{2}$,
} Pieter G Tepper ${ }^{1}$, Frank AE Kruyt ${ }^{2}$ and Wim J Quax ${ }^{1 *}$

\section{Correction}

The figure numbering in the HTML version of the original article (van Roosmalen et al. 2014) was listed incorrectly, while the PDF version was correct.

Figure 1 in the HTML version is Figure 2 in PDF

Figure 2 in the HTML version is Figure 3 in PDF

Figure 3 in the HTML version is Figure 4 in PDF

Figure 4 in the HTML version is Figure 5 in PDF

Figure 5 in the HTML version is Figure 6 in PDF

Figure 6 in the HTML version is Figure 7 in PDF

Figure 7 in the HTML version is a duplicate of additional

Figure S3.

The publisher would like to apologise for this error.

\begin{abstract}
Author details
'Department of Pharmaceutical Biology, Groningen Research Institute of Pharmacy, University of Groningen, Antonius Deusinglaan 1, Groningen 9713 $\mathrm{AV}$, The Netherlands. ${ }^{2}$ Department of Medical Oncology, University of Groningen, University Medical Center Groningen, Hanzeplein 1, Groningen $9713 \mathrm{GZ}$, The Netherlands. ${ }^{3}$ Present address: Department of Cell Biology, UT Southwestern Medical Center, Dallas, TX 75390-9039, USA. ${ }^{4}$ Present address: Department of Pulmonary Medicine, Erasmus Medical Center, Westzeedijk 353, Rotterdam 3015 AA, The Netherlands.
\end{abstract}

Received: 8 December 2014 Accepted: 10 December 2014

Published: 15 December 2014

\section{Reference}

van Roosmalen IAM, Reis CR, Setroikromo R, Yuvaraj S, Joseph JV, Tepper PG, Kruyt FAE, Quax WJ (2014) The ER stress inducer DMC enhances TRAIL-induced apoptosis in glioblastoma. SpringerPlus 3(1):495

Submit your manuscript to a SpringerOpen ${ }^{\circ}$ journal and benefit from:

- Convenient online submission

- Rigorous peer review

- Immediate publication on acceptance

- Open access: articles freely available online

- High visibility within the field

- Retaining the copyright to your article

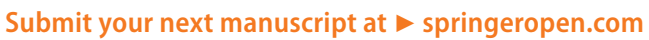

\section{实}

(c) 2014 van Roosmalen et al.; licensee Springer. This is an Open Access article distributed under the terms of the Creative Commons Attribution License (http://creativecommons.org/licenses/by/4.0), which permits unrestricted use, distribution, and reproduction in any medium, provided the original work is properly credited. 